\title{
The ultimate holding company, corporate governance mechanism, and information transparency of listed companies
}

\author{
Gong Zhi-wen and Xu An \\ School of Management and Economics, Jingdezhen Ceramic Institute, Jingdezhen 333001 , \\ China
}

Key words: the ultimate controlling shareholders; Controlling shareholders encroach on; Information transparency; Corporate governance mechanism

\begin{abstract}
: this article from the perspective of ultimate controlling shareholder characteristics and corporate governance mechanism, the building two-period dynamic behavior financial theory model and empirical study on the method of combining with time window of shenzhen in 2009-2013 data of listed companies as samples, to study the relations of ultimate controlling shareholder and corporate information transparency. Study found that: based on the control of the pursuit of self-interest, the ultimate controlling shareholders of listed companies in information manipulation, and as the controlling shareholder control with the increase of the degree of separation of cash flow right, this kind of information manipulation get intensified; On the contrary, raising the level of cash flow right, the improvement of company internal and external governance mechanism, is to some extent inhibited the excessive information manipulation, which increases the transparency of information.
\end{abstract}

\section{The controlling shareholders}

(1) the controlling shareholders encroach on information transparency with the company

Within the scope of the time, ownership concentration and the big shareholder control become a common phenomenon in the listed company, the company's agency problems mainly for controlling agency problems between large shareholders and external medium and small investors. Actual control people often use the pyramid structure, cross-shareholdings and dual share structure, control and the separation of cash flow rights. When actual controllers and control the greater the degree of separation of cash flow right, the greater the chance of occupy listed company interests (LaPorta, etc., 1999; Claessens, etc., 2002) [1-2]. Accordingly, the listed company information disclosure problem could be affected by this kind of agency problem [3-4]. Ma Zhonghe xiang-yu wu (2007) found the ultimate control person, the greater the separation of control and cash flow right, the lower the degree of information disclosure of listed companies 。

(2) corporate governance mechanisms and corporate information transparency

Corporate governance mechanisms include not only includes the external governance mechanisms, such as legal, cultural, political, economic, also includes the internal governance mechanism, external institutional ownership, board system, etc.). La Porta et al. Studies have shown that compared with the common law countries, civil law countries to protect the interests of the investors are relatively weak, big shareholders' "tunneling" behavior is relatively serious, unsound investors protection laws to reduce the quality of the accounting information [6]. Bushman et al., found that a country's accounting information quality is related to its political and economic environment, while more transparent governance depends on the country's legal system [7]. Zhao Ying (2012) study found that the governance environment on the influence of non-financial information disclosure show some effect, but not to the enterprise financial information disclosure regulation is limited [8]. To sharp, etc. (2012) to the shenzhen stock exchange during 2004-2007 family of listed companies as samples, the study found that the marketization degree, the rule of law to the family holding enterprise information disclosure quality has significantly positive impact, and the degree of government intervention, no significant difference to the quality of corporate disclosure [9]. Wang Huacheng (2007) analysis of listed companies in China such as inner relationship between governance structure and earnings quality. The study found that: the role of 
independent director governance is still not fully [10]. Dechow, etc. (1996) found that profit manipulation of the company's CEO is more likely to serve as chairman of the board [11]. Gul and Leung (2004), "the chairman and general manager position and lower corporate disclosure level。

Combined with the literature review above, put forward in this paper, the need to test the hypothesis:

H1: the higher the level of cash flow right of controlling shareholders, the company's disclosure transparency is higher;

H2: control and the greater the degree of separation of cash flow right of controlling shareholders, company information manipulation phenomenon is more serious;

H3: the company's internal governance mechanism, the more perfect, the lighter is company information manipulation phenomenon. Governance mechanisms including the chairman and general manager of situation, the independent directors proportion, as well as the external institutional investors holding, etc。

H4: external governance mechanism, the more perfect, the lighter is company information manipulation phenomenon. External governance mechanisms including the degree of marketization, the degree of government intervention and the rule of law level, etc o

\section{2. the research design}

\section{(1) sample selection and data sources}

This paper choose 2009-2013 in shenzhen stock exchange main board listed companies and small and medium-sized plate listed companies as research samples, primary filtered according to the following standards on the original sample: eliminate belongs to the financial and insurance companies; Weed out control of the actual control of people is less than $10 \%$ shares of the listed company; Weed out the data of the listed company; Excluding continuous variable outside 3 times the standard deviation of sample companies (including asset-liability ratio is greater than 1 or less than zero, ROA is less than 1). Eventually contains observations in shenzhen 5 years a total of 2889 samples, 467, 2010, 2010, 2009, 2011, 2011, 2012, 648, 648, 704 sample observations. The ultimate controlling shareholder data, this paper from the annual reports of control chain chart manually to sort out. External governance environment data, the use of fan and so on by the index of marketization of China's regional market relative process 2015 report of the related index. The listed company information disclosure quality data from shenzhen stock exchange website "integrity file" information disclosure evaluation results; The company's financial data and corporate governance according to the data the taian CSMAR database after finishing.

\section{(2) the research model}

This paper establish a Logistic regression equation (10), comprehensive test of the actual control of cash flow rights, control, and the separation of cash flow right and corporate governance mechanism of the influence of information disclosure transparency. Equation (10) is used to test hypothesis $\mathrm{H} 1$, and hypothesis of hypothesis $\mathrm{H} 2, \mathrm{H} 3$ and hypothesis $\mathrm{H} 4$, when the equation (1) the coefficient of B1 for timing, hypothesis H1 verified; Significant negative abnormal coefficient of B2, hypothesis H2 verified; When the coefficient of B6 and B7 is significantly positive, coefficient of B8 significantly negative, hypothesis H3 verified; When the coefficient of B3 and B4 and B5 for timing, hypothesis $\mathrm{H} 4$.

$$
\begin{aligned}
\text { Tran }= & \beta_{0}+\beta_{1} \text { Cash }+\beta_{2} \text { Sep }+\beta_{3} \text { Mar }+\beta_{4} \text { Gov }+\beta_{5} \text { Leagl }+\beta_{6} \text { Indep }+\beta_{7} \text { Insti }+\beta_{8} \text { Dual } \\
& +\beta_{9} \text { Lev }+\beta_{10} \text { Size }+\beta_{11} \text { ROA }+\sum_{i=1}^{11} \beta_{11+i} \text { Indus }+\sum_{j=1}^{4} \beta_{22+j} \text { Year }+\varepsilon
\end{aligned}
$$

Among them, considering the multicollinearity, the variable Cash and Sep, and Mar,.gov and Legal alternative was introduced into the actual regression analysis model, respectively 。 


\section{3. the empirical results and analysis}

\section{(1) descriptive statistical analysis}

Samples failed the company overall information disclosure evaluation results for $2.90 \%, 25.91 \%$ for examination and assessment of information disclosure in the exam, interest disclosure evaluation for good (60.56\%), and information disclosure for the outstanding accounts for $10.63 \%$. Description of the listed company information disclosure condition overall is good. With the constant improvement of China's capital market, information disclosure transparency situation is gradually improving 。

Descriptive statistical analysis results show that the average $30.8873 \%$ cash flow right, the separation of cash flow rights and control degree of average is $0.2062 \%$, shows that the listed company two rights separation phenomenon is relatively serious, the ultimate controlling shareholders of listed companies through the hold less cash flow right caused the separation of cash flow rights and control. Separation degree is the minimum value of 0 at the same time, the maximum value is 0.9793 , that separating degree has great difference between different companies. It also preliminarily verified the hypothesis $\mathrm{H} 2 \mathrm{H} 1$ and hypothesis. The chairman and general manager, who averages 0.1919 , the independent directors proportion averages of 0.3585 , external institution equity averages of 12.8546, shenzhen listed company internal governance mechanism is explained overall is good, but the maximum and the minimum between these different companies indicator is put in bigger difference, explain company internal governance mechanism of listed companies has bigger difference. Marketization level, degree of government intervention and the rule of law of the maximum and the minimum gap between the larger, according to external governance environment differences between regions in China is more obvious 。

\section{(2) the correlation analysis}

Pearson correlation test of each variable, as shown in table 1, corporate transparency and disclosure of information control and cash flow right, the deviation degree of negative correlation with the cash flow right is significantly related to the significance level of $5 \%$. Control of ultimate controlling shareholder and cash flow right deviation on the company's information disclosure transparency has a significant negative influence, for the significant positive influence on cash flow right. With the above theoretical analysis and the research hypothesis is consistent. External governance mechanism variables, marketization, and the rule of law with the company's information disclosure transparency in $5 \%$ is significantly related to the level of degree of reduce government intervention in the level of $5 \%$ significant negative correlation. Other control variables and the relationship between corporate disclosure transparency is also consistent with the above forecast symbols. 
Table 1, each variable Pearson correlation test

\begin{tabular}{|c|c|c|c|c|c|c|c|c|c|c|c|c|}
\hline & Tran & Cash & Sep & Dual & Indep & Insiti & Mar & Legal & Gov & Lev & Size & $\begin{array}{c}\mathrm{RO} \\
\mathrm{A}\end{array}$ \\
\hline Tran & 1 & & & & & & & & & & & \\
\hline Cash & $0.130^{* *}$ & 1 & & & & & & & & & & \\
\hline Sep & $-0.080^{*}$ & $-0.651^{*}$ & 1 & & & & & & & & & \\
\hline Dual & -0.025 & -0.023 & 0.021 & 1 & & & & & & & & \\
\hline Inde & 0.026 & $0.041^{*}$ & -0.036 & $0.066^{* *}$ & 1 & & & & & & & \\
\hline Insiti & $0.102^{* *}$ & $-0.093^{*}$ & 0.036 & -0.011 & 0.027 & 1 & & & & & & \\
\hline Mar & $0.116^{* *}$ & 0.022 & -0.005 & $0.103^{* *}$ & $0.056^{* *}$ & $0.130^{*}$ & 1 & & & & & \\
\hline Lega & $0.094^{* *}$ & 0.001 & 0.016 & $0.140^{* *}$ & $0.046^{*}$ & $0.149^{*}$ & $0.738^{* *}$ & 1 & & & & \\
\hline Gov & $0.047^{*}$ & 0.030 & 0.000 & $0.070^{* *}$ & 0.011 & 0.028 & $0.671^{* *}$ & $0.706^{* *}$ & 1 & & & \\
\hline Lev & $-0.139^{*}$ & $-0.079^{*}$ & $0.041^{*}$ & $-0.058^{*}$ & $-0.055^{*}$ & 0.000 & $-0.132^{*}$ & $-0.126^{*}$ & $-0.049^{*}$ & 1 & & \\
\hline Size & $0.136^{* *}$ & $0.156^{* *}$ & $-0.096^{*}$ & $-0.129^{*}$ & -0.019 & $0.159^{*}$ & 0.017 & -0.012 & -0.022 & $0.326^{* *}$ & 1 & \\
\hline ROA & $0.179^{* *}$ & $0.072^{* *}$ & -0.005 & 0.010 & -0.007 & $0.083^{*}$ & $0.130^{* *}$ & $0.112^{* *}$ & $0.067^{* *}$ & $-0.315^{*}$ & $0.065^{*}$ & \\
\hline
\end{tabular}

(3) the multiple regression analysis

The rest of this article using the established model, the use of logistic regression analysis method to test the above hypothesis 。

From table 2 model 1, 2, and 3 can be found that the coefficient is positive cash flow right and are significant at the $1 \%$ level, so as to verify the hypothesis $\mathrm{H} 1$ in this paper. This shows that with the increase of level of cash flow right, the controlling shareholders encroach on the opportunity cost of increased, the access control self-interest motivation to reduce, the degree of information manipulation is correspondingly reduced. From table 3 model 1, 2, and 3 can be found that the two rights separation degree and the information transparency is significantly negative correlation, $1 \%$ significance level, this article assumes that $\mathrm{H} 2$ is verified. This shows that the ultimate controlling shareholders two rights separation degree, the greater the access to the private benefits and direct encroach on the motives of listed companies is more intense, in order to cooperate with the control of self-interest behavior, control of ultimate controlling shareholders will use its manipulation of information, reduce the company's disclosure transparency 。

From model 1 of table 2 and table 3 model 1 as you can see, the marketization degree on the $1 \%$ level and information transparency, that with the improvement of the company area marketization level, the quality of information disclosure of listed companies also increases accordingly; 2 models in the table 2, table 3 model 2 you can see, reduce the degree of government intervention and the information transparency, significance level of 5\%. The results showed that the smaller the government intervention, the higher the quality of information disclosure of listed companies. From model 3 in table 2 and table 3 model 3 can be found, and positively related to the information transparency at the level of the rule of law, both in the $10 \%$ significance level, the company area the higher the level of rule by law, the company's information disclosure quality has also been improved accordingly. To verify the hypothesis $\mathrm{H} 4$ in this paper. That external governance mechanism significantly affect the quality of corporate information. Can be seen from table 2 and table 3, the company's internal governance mechanism variables, chairman and general manager of part-time situation is negatively related to the company information disclosure transparency, the 
independent directors proportion with the company's information disclosure transparency, but were not significant.

Table 2, the cash flow rights and corporate governance mechanism and information disclosure quality of logistic regression results

\begin{tabular}{|c|c|c|c|c|c|c|}
\hline & \multicolumn{2}{|c|}{ Model 1} & \multicolumn{2}{|c|}{ Model 2} & \multicolumn{2}{|c|}{ Model 3} \\
\hline & $\begin{array}{c}\text { The } \\
\text { coefficient } \\
\text { of B }\end{array}$ & Wald & $\begin{array}{c}\text { The } \\
\text { coefficient } \\
\text { of B }\end{array}$ & Wald & $\begin{array}{c}\text { The } \\
\text { coefficient } \\
\text { of B }\end{array}$ & Wald \\
\hline $\begin{array}{c}\text { The constant } \\
\text { term }\end{array}$ & $-6.148 * * *$ & 35.960 & $-5.851 * * *$ & 33.038 & $-5.760 * * *$ & 32.151 \\
\hline Cash & $0.012 * * *$ & 21.348 & $0.013 * * *$ & 21.939 & $0.012 * * *$ & 21.131 \\
\hline Mar & $0.082 * * *$ & 12.250 & & & & \\
\hline Legal & & & $0.026 * *$ & 5.190 & & \\
\hline Gov & & & & & $0.026^{*}$ & 2.839 \\
\hline Dual & -0.140 & 1.615 & -0.137 & 1.542 & -0.122 & 1.238 \\
\hline Indep & 0.693 & 0.612 & 0.755 & 0.725 & 0.754 & 0.724 \\
\hline Insiti & $0.009 * *$ & 4.832 & $0.009 * *$ & 5.014 & $0.009 * *$ & 4.894 \\
\hline Lev & $-1.533 * * *$ & 34.820 & $-1.565 * * *$ & 36.443 & $-1.597 * * *$ & 38.060 \\
\hline Size & $0.316^{* * * *}$ & 44.179 & $0.322 * * *$ & 46.033 & $0.324 * * *$ & 46.709 \\
\hline $\mathrm{ROA}$ & $3.480 * * *$ & 29.629 & $3.551 * * *$ & 30.598 & $3.562 * * *$ & 30.685 \\
\hline Industry & \multicolumn{2}{|c|}{ Control } & \multicolumn{2}{|c|}{ Control } & \multicolumn{2}{|c|}{ Control } \\
\hline Year & \multicolumn{2}{|c|}{ Control } & \multicolumn{2}{|c|}{ Control } & \multicolumn{2}{|c|}{ Control } \\
\hline Chi-square & \multicolumn{2}{|c|}{$294.674 * * *$} & \multicolumn{2}{|c|}{$287.694 * * *$} & \multicolumn{2}{|c|}{$285.265^{* * *}$} \\
\hline Nagelkerke- $^{2}$ & \multicolumn{2}{|c|}{0.138} & \multicolumn{2}{|c|}{0.135} & \multicolumn{2}{|c|}{0.134} \\
\hline Sample size & \multicolumn{2}{|c|}{2898} & \multicolumn{2}{|c|}{2898} & \multicolumn{2}{|c|}{2898} \\
\hline
\end{tabular}


Table 3, the degree of separation of cash flow rights and control, corporate governance mechanism and information disclosure quality of logistic regression results

\begin{tabular}{|c|c|c|c|c|c|c|}
\hline & \multicolumn{2}{|c|}{ Model 1} & \multicolumn{2}{|c|}{ Model 2} & \multicolumn{2}{|c|}{ Model 3} \\
\hline & $\begin{array}{c}\text { The } \\
\text { coefficient } \\
\text { of B }\end{array}$ & Wald & $\begin{array}{c}\text { The } \\
\text { coefficient } \\
\text { of B }\end{array}$ & Wald & $\begin{array}{c}\text { The } \\
\text { coefficient } \\
\text { of B }\end{array}$ & Wald \\
\hline $\begin{array}{c}\text { The constant } \\
\text { term }\end{array}$ & $-6.090 * * *$ & 35.023 & $-5.777 * * *$ & 31.988 & $-5.706 * * *$ & 31.314 \\
\hline Sep & $-0.492 * *$ & 8.782 & $-0.497 * * *$ & 8.967 & $-0.485 * * *$ & 8.542 \\
\hline Mar & $0.084 * * *$ & 12.888 & & & & \\
\hline Legal & & & $0.027 * *$ & 5.382 & & \\
\hline Gov & & & & & $0.028 *$ & 3.463 \\
\hline Dual & -0.147 & 1.791 & -0.144 & 1.706 & -0.129 & 1.389 \\
\hline Indep & 0.706 & 0.637 & 0.772 & 0.763 & 0.770 & 0.758 \\
\hline Insiti & $0.007 *$ & 3.095 & $0.007^{*}$ & 3.251 & $0.007 *$ & 3.167 \\
\hline Lev & $-1.605 * * *$ & 38.272 & $-1.637 * * *$ & 39.997 & $-1.669 * * *$ & 41.672 \\
\hline Size & $0.338 * * *$ & 51.628 & $0.344 * * *$ & 53.660 & $0.346^{* * *}$ & 54.403 \\
\hline ROA & $3.595 * * *$ & 31.179 & $3.672 * * *$ & 32.275 & $3.676^{* * *}$ & 32.252 \\
\hline Industry & \multicolumn{2}{|c|}{ Control } & \multicolumn{2}{|c|}{ Control } & \multicolumn{2}{|c|}{ Control } \\
\hline Year & \multicolumn{2}{|c|}{ Control } & \multicolumn{2}{|c|}{ Control } & \multicolumn{2}{|c|}{ Control } \\
\hline Chi-square & \multicolumn{2}{|c|}{$1281.608 * * *$} & \multicolumn{2}{|c|}{$274.199 * * *$} & \multicolumn{2}{|c|}{$272.183^{* * *}$} \\
\hline Nagelkerke-R $^{2}$ & \multicolumn{2}{|c|}{0.132} & \multicolumn{2}{|c|}{0.1299} & \multicolumn{2}{|c|}{0.128} \\
\hline Sample size & \multicolumn{2}{|c|}{2898} & \multicolumn{2}{|c|}{2898} & \multicolumn{2}{|c|}{2898} \\
\hline
\end{tabular}

\section{References}

[1] La Porta,R.,F.Lopez-de-Silanes,A.Shleifer.Corporate Ownership around the World [J]. Journal of Finance, 1999, 54 (2): 471-517.

[2] Claessens S.,S. Djankov,J.Fan,L.Lang.Disentangling the Incentive and Entrenchment Effects of Large Shareholdings [J].Journal of Finanrce,2002, 57 (6) :2741-2771.

[3] Gul F.A.,Leung S.Board leadership, outside directors' expertise and voluntary corporate disclosures[J].Journal of Accounting and Public Policy,2004,23:351-379.

[4] Lopez-de-Silanes F,Shleifer A,Vishny R.Investor Protection and Corporate Governance[J].Journal of Financial Economics,2000,58(1-2):3-27.

[5] R.J.Bushman,Piotroski,A.Smith.What Determines Corporate Transparency[J].Journal of Accounting Research,2004,42(2):207-252.

[6] Dechow P.M.,Sloan R.G.,Sweeney A.P.Causes and Consequences of Earnings Manipulation: An Analysis of Firms Subject to Enforcement Actions by the SEC[J].Contemporary Accounting Research,1996,13(1):1-36. 